\title{
Quality of Genetically-Improved Acacia auriculiformis for Renewable Short-Rotation Wood-Energy
}

\author{
Rina Laksmi Hendrati*, Siti Husna Nurrohmah
}

Center for Forest Biotechnology and Tree Improvement,

Ministry of Environment and Forestry Jl. Palagan T. Pelajar km 15, Purwobinangun, Pakem, Yogyakarta 55582, Indonesia

Received May 23, 2018/Accepted November 11, 2018

\begin{abstract}
To be viable, fast-growing energy plantations must be large in volume, harvested at early age, and maximized calorific value which linked to heartwood proportion. This study examines 38 families in the second generation $\left(F_{2}\right)$ progeny trial of Acacia auriculiformis for energy. Heartwood proportion, calorific value and lignin content were assessed at ages 22, 30, 35, and 40 months. Wood samples from around 300 selected individuals of observed ages from all families were examined. Quality was based on heartwood and sapwood development until reaching the commercial requirement of $>33 \%$ for lignin content and $>4,500 \mathrm{cal}^{-1}$ for calorific value. When required quality has been obtained at particular age, assessment of biomass was carried out from all final individuals in the progeny test. Heartwood proportion varies among families. Heartwood possesses higher values than sapwood in lignin content and calorific value. Individuals with higher heartwood proportion are preferred. Both wood types only reached the required quality for solid wood energy after 3.5 years, however lignin content at much early age are appropriate for wood pellet and briquette. Selection improves heartwood proportion and quality from the first generation $\left(F_{1}\right)$ into $F_{2}$ with an increase of $52 \%$ at three years. Mean annual increments at 3.5 years is $43 \mathrm{~m}^{3} \mathrm{ha}^{-1} \mathrm{yr}^{-1}$.
\end{abstract}

Keywords: genetic improvement, A. auriculiformis, biomass, energy, rotation

*Correspondence author, email: rina.l.hendrati@biotifor.or.id, tel. +62-274-896080, +62-274- 895954, fax +62274-896080

\section{Introduction}

To be economically viable, energy plantations must be fast-growing so that large volumes of wood could be harvested at an early age and meet the standard quality (Apiolaza 2009; Krzyzaniak et al. 2014). In term of wood for energy, quality is strongly associated with its calorific value (Stolarski 2014) which is often linked to the existence of heartwood (Eberhard 1990). Acacia auriculiformis is a fastgrowing species that potentially meet the requirements, and it is highly suited to planting in a large range of Indonesian environments. Rotation lengths of unimproved planting stock of this species, when grown for fuelwood, can vary between four years in China (Zhigang \& Minquan 1987) and eight years in Bangladesh (Islam et al. 2013). However, with a genetic improvement that has been carried out for this species, it is important to find the proper rotation age for energy-wood. This might be influenced by several factors, including the source of genetic materials, environment, spacing, and maintenance. This study (undertaken by using genetically improved individuals) is expected to select the best genotypes for deployment and for developing mass scale production. The success of this action not only provide a carbon-neutral renewable-energy source but also help the community to fulfill their fuelwood needs, without destroying surrounding woodlands and forests. In addition, this fast-growing species also capture more abundant carbon from the atmosphere for climate change mitigation, than the slower one. Further, having abilities to coppice for branch harvest while securing cut back the main stem and grow well in marginal sites, this species help maximizing land cover with vegetation, thus useful for maintaining the ecosystem.

In general, heartwood is higher in calorific value and lignin content than sapwood (Eberhard 1990; Sitoputro 2014). The heartwood portion is characterized by higher extractive constituent than sapwood in which those factors determine woods' heating value (Bowyer et al. 2007). Heartwood portion is highly varied within species, and it is genetically controlled (Zobel \& Jett 1995), therefore selection of individuals with the highest proportion of heartwood is expected to improve wood quality for energy. Heartwood portion of $A$. auriculiformis stem varies significantly on each tree (Susanto et al. 2008), then it is important to select $A$. auriculiformis tree with large heartwood portion. Heartwood portion in tree trunk increases with age (Des Santos Lourenço 2008; Moya \& Berrocal 2010).

Large heartwood portion is potentially produce good 
wood quality for energy with higher lignin content and greater extractive compounds and expectedly higher calorific value. In a plant, lignin content determines its possibility for an energy source (McKendry 2002), partly because it affects the heating value (Bowyer et al. 2003). For energy purpose in the form of a wood pellet, wood with high lignin content are also advantageous due to its ability to bind wood powder forming sturdier wood pellet (Hafrén et al. 1999). It also causes materials to be less moist because lignin is much less hygroscopic (Panshin \& de Zeeuw 1980), hence increasing wood resistance against biodegradation (Bowyer et al. 2003) useful for storage.

Wood calorific value or heat of combustion is the most common parameter used to compare the quality of fuelwood (Eberhard 1990; Dermibas 2009). The calorific value per unit of wood biomass is positively correlated with lignin content (Dermibas 2003; Dermibas 2009). This means higher lignin content would produce higher heating value, although other extractives could also be influential (Bowyer et al. 2003; Zhonglian 2009). Due to its higher degree of oxidation, wood cellulose is less heat value than lignin (Demirbas \& Demirbas 2009). Observation of calorific value of many species including ten acacia species by Eberhard (1990) showed that heartwood contains higher calorific value than sapwood, and specifically, Sitoputro (2014) also reported that the heartwood of $A$. auriculiformis is higher in calorific value than its sapwood. Without detail information on its wood quality, A. auriculiformis has also been used for fuelwood in China with four-year rotation (Zhigang \& Minquan 1987). Heartwood in woody plants has been so important to determine the quality, and it implies proper rotation. This is also exemplified in tree species Bombacopsis quinata which heartwood content rises with increasing age and its rotation period needs to be extended to achieve heartwood requirement for producing quality timber (Perez 2004).

Similarly, for $A$. auriculiformis which genetic improvement in the first generation (F1) showed a wide variation of heartwood proportion ranging from $11-22 \%$ at 3 years old (Susanto et al. 2008), it would be expected to increase more of its proportion because of age and selection from $F_{1}$ to second generation $\left(F_{2}\right)$. During the selection process, the best individuals were left for growth and heartwood proportion, for better quality wood energy and for determining proper rotation. For plantation manager point of view, uniform material of the tree will gain efficient and effective process in the bioenergy industry. Uniformity and continuity of wood energy material would determine the scale of industries (Hendrati et al. 2011). Therefore, particular age of woody plants with similar heartwood and sapwood portions will be influential for running woodenergy industry. Increased lignin has also been known as an important character in wood energy for direct firing or cofiring (Hinchee et al.2009).

This paper studies the wood quality in term of wood energy by observing heartwood portion and examines the suitability of wood from $\mathrm{F}_{2}$ genetically-improved $A$. auriculiformis by confirming it with essential characters for energy-wood which are lignin content and calorific value. It is expected that its quality will increase with age and there will be a particular age for A. auriculiformis to achieve sufficient quality for wood-energy.

\begin{abstract}
Methods
Materials Experiment was conducted with materials from $\mathrm{F}_{2}$ progeny test which was established by using the best 38 families from $\mathrm{F}_{1}$ established by Susanto et al. (2008). Each family of $\mathrm{F}_{2}$ was set randomly in four tree plot/block and replicated into ten blocks at $4 \times 2 \mathrm{~m}$ spacing totaling about 1,520 trees. Assessments of heartwood portion were carried out in 22,30 , and 36 months by culling one worst individual in growth at each age, within the four-tree-plot families, in the form of three cm-width disks. Final heartwood proportion was assessed at 40-months from the final best standing tree within the family by drilling the stem at diameter breast height (dbh). The two-cm diameter drill was used to remove a wood sample across the trunk diameter of the final living individuals. The wood samples both from the disks and the drilled samples were used for lignin content and calorific values test in the laboratory. For lab analysis, wood samples were collected from individuals of four most uniform blocks (block 1, 3, 5, and 9). Laboratory assessments were only undertaken to 30 and 36-month trees as scoping trial from the disk samples, 40 months from the drilled samples for lignin content and similar samples of 30 and 40 months for calorific values (Sitoputro 2014).
\end{abstract}

Heartwood proportion and sample preparation Diameter of disks and heartwood parts were measured from two directions across the disks with $90{ }^{\circ} \mathrm{C}$ angle in between. Heartwood portions were assessed by measuring the darker heartwood portion out of the whole disk area. Further, an electric handsaw (Maktec type P45-6530) was used to cut apart the sapwood from the heartwood from the disks $(22,30$, and 35 months) and drilled (40 months) samples. After being oven dried at $80^{\circ} \mathrm{C}$ for two days, both samples were labelled according to family and tree numbers. Heartwood and sapwood of each sample were divided into two different sample forms (1) into $34 \mathrm{~g}$ powder by grating/grinding the samples for lignin content analyses and (2) into $0.5 \mathrm{~g}$ of dried flakes used for calorific value assessment. Samples were taken from sapwood and heartwood-formed samples only (Sitoputro 2014).

Lignin content analysis Lignin content was analyzed using Chesson-Datta method (Datta 1981) and corrected by ash content, which was carried out with sequential fractionation and gravimetric method. One gram of sawdust sample was refluxed for two hours in $150 \mathrm{~mL} \mathrm{H}_{2} \mathrm{O}$ at $100{ }^{\circ} \mathrm{C}$ using hot water soluble to extract pectin and oligosaccharides. In order to get rid of hemicelluloses, dried residue was refluxed for two hours with $150 \mathrm{~mL}$ of $\mathrm{H}_{2} \mathrm{SO}_{4}$ at $100 \mathrm{C}$. To remove dried Cellulose residue, the sample was treated with $10 \mathrm{~mL} 72 \%$ $\mathrm{H}_{2} \mathrm{SO}_{4}(\mathrm{v} / \mathrm{v})$ at room temperature for four hours, then it was diluted to $0.5 \mathrm{M} \mathrm{H}_{2} \mathrm{SO}_{4}$ and refluxed at $100{ }^{\circ} \mathrm{C}$ for two hours. Then to remove the ash dried residue, samples were burned down in a huffle furnace (Heraeus MM 110) in $575 \pm 25^{\circ} \mathrm{C}$ for five hours. The leftover residue was lignin which was remained and ready for measurement.

Lignin content percentage corrected by ash content, were calculated using the Equation [1] (Datta 1981).

Lignin $(\%)=((\mathrm{d}-\mathrm{e}) / \mathrm{a}) \times 100 \%$

note: a: sample's oven-dry weight (ODW) (g), d: oven-dry weight (ODW) of the residue after treated with $72 \% \mathrm{H}_{2} \mathrm{SO}_{4}$ 
and $0,5 \mathrm{M} \mathrm{H}_{2} \mathrm{SO}_{4}(\mathrm{~g})$, e: $\operatorname{ash}(\mathrm{g})$.

Measurement of the calorific value Gross calorific values were measured in a bomb calorimeter in two steps by first determining the average value for a benzoic standard and then the sample (ASTM D-2015). The amount of $0.5 \mathrm{~g}$ dried flakes were placed in the calorimeter which was prepared and ready for use for 15-minute analyses. Once the temperature is constant, the bomb was turned off and the final temperature is recorded. The GCV of each sample was calculated as shown Equation [2]:

$$
\mathrm{GCV}=((\mathrm{EE} \Delta \mathrm{t})-(\text { Acid })-(\text { Fuse })) / 5 \mathrm{~m}
$$

note: $\mathrm{EE}=$ standard capacity of the calorimeter $\left(\mathrm{cal} \mathrm{C}^{-1}\right), \mathrm{m}=$ mass of benzoic acid tablet $(\mathrm{g}), \Delta \mathrm{t}=$ temperature difference (C), Acid = amount of heat obtained from the titration procedure $\left(1.4 \mathrm{cal} \mathrm{mL}^{-1}\right.$ titrant $)$, Fuse $=$ the amount of heat that is used to burn the fuse $\left(2.3 \mathrm{cal} \mathrm{cm}^{-1}\right)$.

Measurement of biomass On each sampling occasion, stand volume was calculated from height, diameter at breast height and multiplied with the correction factor of 0.33 . Total biomass was estimated from the stem and branches in which for A. auriculiformis the proportion is about $79 \%$ from the stem and 21\% from branches (Zhigang \& Minquan 1987). This wood-biomass was assessed by calculating the main trunk volume assigned as $79 \%$, while the branches volume were assumed as the leftover percentage (21\%) and it was calculated and added to make a total volume of a tree $(100 \%)$.

Data analyses Lignin content was measured by using Chesson-Datta method described before. Calorific value was assessed by using Bomb Calorimeter described above T-test analyses were undertaken for lignin content and calorific values for both wood types, heartwood and sapwood, at different ages. Graphics were figured to describe the differences in heartwood proportions among ages, and the comparisons of lignin content and calorific values between sapwood and heartwood with times.

\section{Results and Discussion}

Heartwood proportion Some $A$. auriculiformis individuals develop heartwood after 22 months, but most individuals have not yet. Therefore, the average heartwood formation after 22 months is still relatively low which is about $19 \%$. There has been a variation on the formation of heartwood in young $A$. auriculiformis among families at 30 months (p < $0.019)$ and that variation is becoming greater $(\mathrm{p}<0.00001)$ after another six months at 36 months (Sitoputro 2014). Records of measurement indicate that this heartwood proportion is increasing with age (Figure 1). Comparison at 3-year-old between the $F_{1}$ generation (Susanto et al. 2008) and the $\mathrm{F}_{2}$ generation indicates that there has been a considerable increase in heartwood proportion up to $53 \%$ from $16.8 \%$ in $F_{1}$ into $25.2 \%$ in $F_{2}$ (Figure 1). After fourth selection in the second generation $\left(\mathrm{F}_{2}\right)$, the proportion increases another $52 \%$ at 40 months.

The heartwood of this species developed continuously throughout the year (Baqui \& Shah 1985). This kind of variations in heartwood proportion has been commonly found in tree species (Eberhard 1990) and is highly genetically controlled (Korinobu et al. 1990; Knigge 1993; Zobel \& Jett 1995). Therefore, it becomes an effective character for selection to screen individuals with best heartwood proportion to approach satisfying gain in timber quality. Commercially, sapwood is less desired because of greater starch and water content causing it less strong, and it is also not suitable for wood-energy. In contrast, heartwood contains dead cells, higher density, having more gas, extractives and tillose making it stronger and more resistant against microorganism (Hills 1987; Bowyer et al. 2007) and the first four characters are also supporting high heating value. High variation of this character in this study, have caused very high heritability values $\left(h^{2}\right)$ of 0.67 at three years and 0.54 at 3.5 years, so it is likely to be highly inherited to the offspring. Accordingly, selected individuals based on best heartwood proportion would be expected to have better quality than those of individuals with a smaller proportion of heartwood.

In breeding, selections have been useful for increasing the average value of selected best individuals (Figure 1), indicating worthy results from the breeding program. The 5year A. auriculiformis plantation established by using bulk seeds of the first generation $\left(\mathrm{F}_{1}\right)$ seed orchard, has shown that the heartwood portion has reached up to $55-67 \%$. This was established by using seeds of the first generation $\left(\mathrm{F}_{1}\right)$ seed orchard which shows a range of $11-22 \%$ heartwood proportion at three years. Although influenced by age, that $A$. auriculiformis plantation grown has shown an increase of $200-400 \%$ heartwood proportion at five years if compared to those of the first generation. For that reason, it is expected that the seeds derived from the second generation $\left(\mathrm{F}_{2}\right)$ seed orchards with an average of $52 \%$ heartwood proportion will produce trees with a much higher range of heartwood proportion which is expected to produce better wood quality for energy. This is because the $\mathrm{F}_{2}$ generation has been

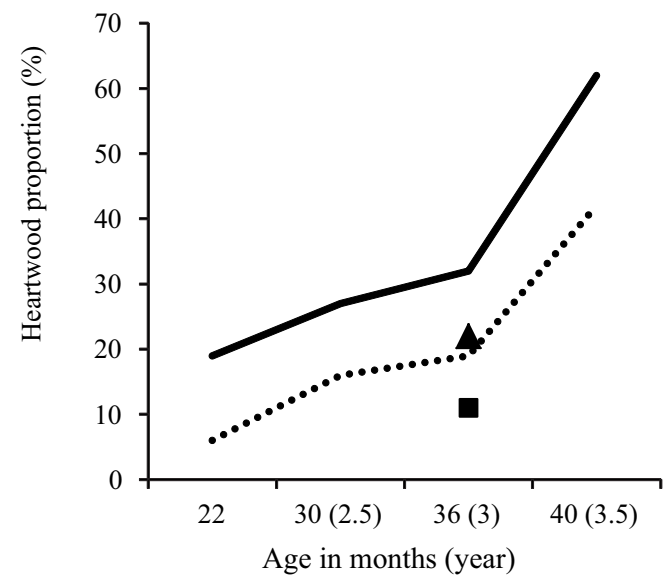

Figure 1 Development of heartwood proportion of $A$. auriculiformis from 22 up to 40 months. (note: Data assessments at 30 and 36 months are also used by Sitoputro 2014). Max second generation (F2) (-), min second generation (F2) ( $\ldots \ldots)$, max first generation $(\mathrm{F} 1)(\mathbf{\Delta})$, min first generation $(\mathrm{F} 1)$ $(\square)$. 


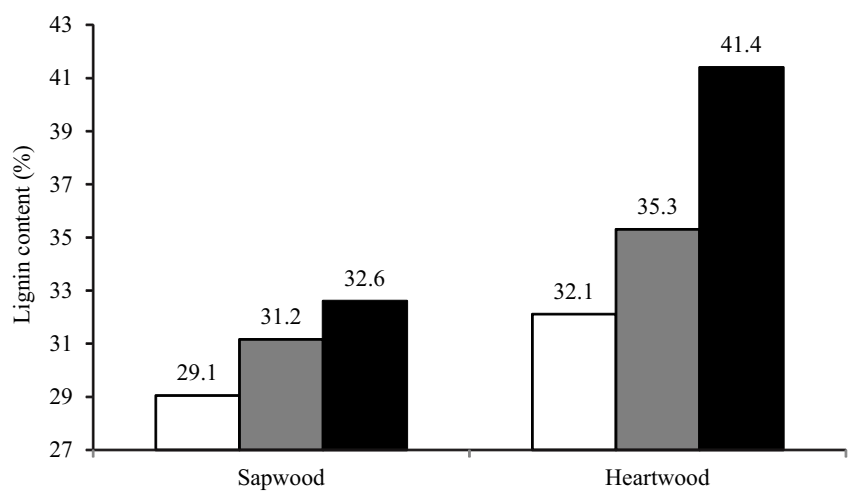

Figure 2 Lignin content of A.auriculiformis sapwood and heartwood at 30, 36, and 40 month old. (Note: data assessments at 30 and 36 months were also used by Sitoputro 2014). 30 months (2.5 yr): sapwood vs heartwood $* * *(\square), 36$ months (3 yr): sapwood vs heartwood * (), 40 months (3.5 yr): sapwood vs heartwood ( $\mathbf{\square})$.

selected based on growth further than the $\mathrm{F}_{1}$.

Lignin content Differences in lignin content, between the two wood types, heartwood and sapwood were found for $A$. auriculiformis grown in the progeny trials. The lignin content values of each age increase from 29 to 31 and $32.6 \%$ at consecutive times of $2.5,3$, and 3.5 years for sapwood and 32 to 35 and $41 \%$ for heartwood (Figure 2) (Hendrati et. al. 2014a, 2014b; Sitoputro 2014). Heartwood tends to possess higher lignin content compared to sapwood at all recorded ages.

High lignin content in energy-wood is essential due to its multi-functions. Referring to the results of this study, selecting this species at an early age to obtain individuals with higher heartwood proportion is an effective approach to get the product with higher lignin content. This is because lignin content has a negative correlation with biomass which indicates that biomass does not warrant high lignin content (Novaes et al. 2010). Lignin content has demonstrated a high positive correlation with heat combustion (Dermibas 2001; Günther et al. 2012), with $r=0.87$ (White 1987) in which in the burning process, oxidation of lignin-bound $\mathrm{C}$ produce high heating value and affect calorific values of the wood (Kataki \& Konwer 2001). In producing wood pellets, the role of lignin is crucial. This amorphous constituent melted in high temperature and solidified when cold (Wilson 2010). Therefore, lignin has a role as "binding agent" (Hafrén et al. 1999), and raw wood materials having high lignin content would reduce the cost for additional binding materials required in wood pellet production. Lignin stabilizes wood dimension (Panshin \& de Zeeuw 1980), in which it also helpful for producing firm wood pellet used for energy. After the high-pressure process during pelleting, it binds the wood cells together forming composite strength. This naturally also occurs within a piece of wood (Dermibas 2004). It is, therefore, essential for pellet durability. It's stability and solid characteristic is also useful to deter water penetration in the wood pellet (Evert 2006), because lignin is much less hygroscopic than cellulose, and lignin would keep the pellet dry, and minimize water adsorption. The wood pellet with water content would decrease heating value (Dermibas 2002) and increase the chance of microorganism invasion (Bowyer et al. 2007).

Lignin content of wood is considered to be high when reaching to $>33 \%$ (Supartini 2009), and lignin content is a character that determines the quality of wood pellet (PeksaBlanchard et al. 2007). The importance of lignin content in biomass for energy has been very common. In an agricultural plant, Sorghum bicolor, lignin content improvement from $20 \%$ to $30 \%$ could increase caloric value, and it has been successfully manipulated by using molecular genetics method (Arif 2018). In this study for A. auriculiformis, high lignin content is achieved at three years for heartwood (35.3\%), but only nearly achieved after 3.5 years for sapwood $(32.6 \%)$. However for wood pellet production, which require the range lignin content of $27-36 \%$, both wood types have been suitable at a rotation of 2.5 years or even earlier. While the levels of temperature and pressure could improve wood pellet calorific value during the processing (Demirbas 2009; Hasan et al. 2017). In the study of pelletizing between wood and many non-wood materials, among the 74 biomass tested, woody biomass is classified as best materials for large-scale pelletization process, especially the stick wood (Gami et al. 2011).

In processing biomass for energy-wood, high lignin content of both, sapwood and heartwood, is important as both wood types will be mixed altogether during the processing. In this study, the heartwood proportion varied in the range of $6.1-50.2 \%$ (average $20.3 \%$ ) at 2.5 years, to 9.5-58.3\% (average $23.8 \%$ ) at three years and rising to 13.7-82.9 (average 54\%) at 3.5 years. Further, selection carried out at 3.5 years had screened final individuals with heartwood proportion in the range of $45-82.9 \%$ (average $52 \%$ ). When calculating both wood types in a mixture, by considering each proportion, lignin content at particular age show an average lignin value of $29.6 \%$ at 2.5 years, $32.15 \%$ at three years and $37 \%$ at 3.5 years. This shows that compared to values at 2.5 and three years old, only lignin content at 3.5 years that warrant higher quality $(>33 \%)$, although less amount will also be appropriate for wood pellet or briquette that can be improved with heating and pressing after grinding. Therefore, it evident that heartwood portion would affect the quality of its wood-energy in term of lignin content, especially when wood-energy is in the form of solid wood products including chips and charcoal. Higher lignin content in heartwood than in sapwood of young $A$. auriculiformis in this study is consistent within Robinia pseudoacacia L. studied by Dünisch et al. (2010) which also shows higher lignin content in heartwood (24.2-25.0\%) than in sapwood (21.4-22.2\%).

Calorific value Heartwood of $A$. auriculiformis has sufficiently high calorific value since 2.5 years (Figure 3 ). Different from heartwood, the sapwood part has not reached the calorific value required by most consumers $(>4500$ cal $\mathrm{g}^{-1}$ ) at 3.5 years. After 3.5 years, however, both wood 


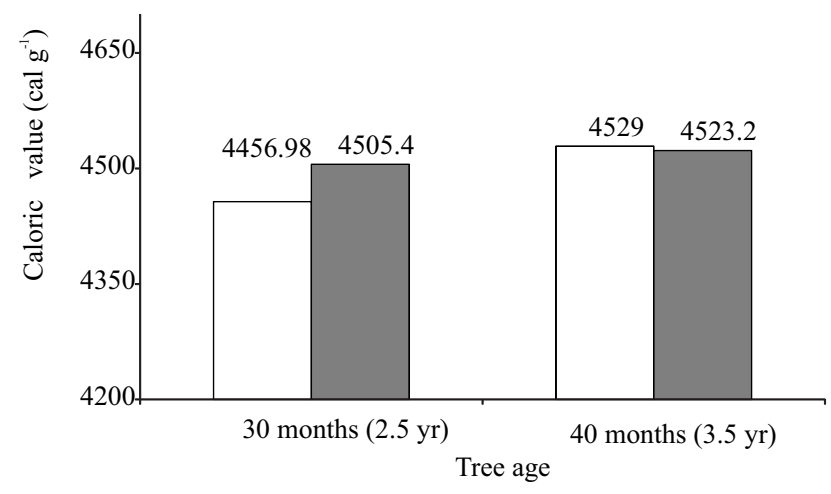

Figure 3 Calorific value of $A$. auriculiformis sapwood and heartwood at 2.5 and 3.5 years old (note: Data assessments at 30 months were also used by Sitoputro 2014). Sapwood ( $\square$ ), 40 Heartwood ( $\square$.

types have exceeds that value (Hendrati et. al. 2014a; 2014b), so that a mixture of both wood types, regardless of each proportion from the selected individuals, will ensure the requisite calorific value.

Caloric value is the foremost character specifying a good quality of energy-wood. High calorific values have been recorded in this species. When it is grown much longer, the wood of this species which burnt without smoke and sparks is potential to reach higher caloric value up to $4,780-5,110 \mathrm{cal}$ $\mathrm{g}^{-1}$ as wood-energy (Zhigang \& Minquan 1987) and 7,322 cal $\mathrm{g}^{-1}$ as charcoal (Syachri 1983). There have been no correlations between lignin content and calorific value of $A$. auriculiformis, both in the sapwood and in the heartwood. Lack of relationship suggests that lignin may not the only constituents associated with the caloric value in this species. Wood constituents other than lignin should affect the calorific value of wood, and this includes a resin (Bowyer $e t$ al. 2007). In this species, further investigation regarding other elements is therefore required.

Similar to lignin content, the calorific value at 3.5 years, also demonstrate appropriate value fulfilling commercial requirements of $>4,500 \mathrm{cal} \mathrm{g}^{-1}$ if assessed as solid wood for chips or charcoal. However, when using A. auriculiformis as materials for wood pellet or briquette, earlier harvest should provide an appropriate quality product as long as appropriate processing is applied. Further with recent request for lower caloric value which is less than $4.500 \mathrm{cal} \mathrm{g}^{-1}$ for industries to minimize heating, much shorter rotation of 2.5-3 years should be applicable. Analysis of calorific potential in trees, including in Eucalyptus grandis and E. urophylla, have been demonstrating common tendency to increase with the increasing age (Santana et al. 2012). Densification in pelletizing is not only improving the heating value but also caloric value. The rising heating value would make the use of biomass for fuel more efficient in combustion and more compatible compared with coal (Dermibas 2009). In addition, denser materials such as wood pellet will also be easier to handle and transport thus significantly reduce the cost of handling.
Biomass Biomass production needs to be estimated when minimum threshold of quality for energy production has been achieved. However, variation among families in biomass production has been very significant $(p<0.0001)$ at 30 and 35 months (Sitoputro 2014), indicating promising gain when carrying out a selection. By considering wood quality criteria for energy, the results demonstrate that minimum year to grow energy plantation from geneticallyimproved A. auriculiformis is suggested at 3.5 years. This is because at 3.5 years, both wood types, heartwood and sapwood, have reached the required qualities as energywood in term of calorific value and lignin content if solid wood is expected for fuelwood, chips, or charcoal production. At this 3.5-year rotation, estimated MAI by using individuals after selection (the best $11.5 \%$ ) based on wood volume will be reaching up to $43 \mathrm{~m}^{3} \mathrm{ha}^{-1}$ year ${ }^{-1}$ (Hendrati et al. 2014a; 2014b; Hendrati 2016) with an average of 52\% heartwood proportion at low soil fertility. This MAI should increase if planted with proper silviculture at more fertile soils.

In breeding program, increasing productivity is nearly always the aim, and this is also the case for genetic improvement of Acacia auriculiformis for wood-energy. In China, dry wood energy of this species produced at 3-5 year rotation, was $24,500 \mathrm{~kg} \mathrm{ha}^{-1}$ which is about $36.6 \mathrm{~m}^{3} \mathrm{ha}^{-1} \mathrm{yr}^{-1}$ with 1,665 trees ha ${ }^{-1}$ (Zhigang \& Minquan 1987) and there has been no available information about the use of selected or improved genotypes for that purpose. Meanwhile, results of this study indicate that the second generation (F2) genotypes at 3.5 years will be estimated to produce higher MAI which is around $43 \mathrm{~m}^{3} \mathrm{ha}^{-1} \mathrm{yr}^{-1}$ (Hendrati et al. 2014a; 2014b ; Hendrati 2016) at dry soil with precipitation of $1,800 \mathrm{~mm} \mathrm{yr}^{-1}$ and should increase at more fertile soils and better silvicultural practices. Without breeding, this species at four year age, demonstrated much lower MAI with $6,720 \mathrm{~m}^{3}$ at 2,222 trees ha $^{-1}$ (Bulgannawar \& Math 1991; Ashaduzzaman et al. 2011). Calculation of samples taken from our plantation established by using F1 bulk seeds from our seed orchard indicate productivity with MAI of $>73 \mathrm{~m}^{3} \mathrm{ha}^{-1} \mathrm{yr}^{-1}$ at five years with $3 \times$ $3 \mathrm{~m}$ spacing, which is much higher than those indicated in China.

Beside genetic factor, potential productivity from the breeding results of this fast-growing species might also be affected by advantageous environmental factors as Indonesia is a tropical country with plenty of rains and sunshine along the year. Compared to Acacia hybrid which has MAI of 48 $\mathrm{m}^{3} \mathrm{ha}^{-1} \mathrm{yr}^{-1}$ (Sunarti et al. 2013), this biomass is a slightly lower. However hybrid of A. auriculiformis with A. mangium although superior in growth may cause lower lignin content due to the suitability of $A$. mangium for pulpwood which requires lower lignin content (Wong et al. 2011). Nevertheless, in comparison to the sub-tropical species, this legume species grow in tropical areas has proven to produce higher yields than hybrid Aspen (Populus spp.) which has been genetically improved for fuelwood and has MAI of 20-25 m $\mathrm{ha}^{-1} \mathrm{yr}^{-1}$ during 20-30 years of rotation in Europe (Tullus et al. 2012). Genetic gain trials by using $\mathrm{F}_{2}$ seeds of this $A$. auriculiformis species have been established at the end of 2016, and it is expected to reveal the realized gain in 
production and its estimation in economic value.

\section{Conclusions}

Heartwood proportion in A. auriculiformis, varies, increasing with time and genetically controlled. Heartwood tends to possess higher lignin content than sapwood in genetically-improved $\mathrm{F}_{2}$ A.auriculiformis at 2.5 and three years. At 3.5 years, both wood types are similarly high in lignin content and caloric values, making it a proper rotation age for harvesting solid wood for energy such as fuelwood, chips, and charcoal. Earlier rotation age will be appropriate for wood pellet and briquette in which the quality of compacting process will determine the quality. At 3.5 rotation age, MAI after final selection is estimated to reach up to $43 \mathrm{~m}^{3} \mathrm{ha}^{-1} \mathrm{yr}^{-1}$ at low soil fertility. This MAI should increase if planted with proper silviculture at more fertile soils. The selection of $A$. auriculiformis during the breeding process has increased heartwood proportion up to $53 \%$ from the $F_{1}$ to the $F_{2}$ when assessed at three years and six months before the rotation age. This study shows that when using genetically improved A. auriculiformis for wood-energy, rotation of $>3$ year is sufficient to produce quality solid-wood with MAI of $43 \mathrm{~m}^{3} \mathrm{ha}^{-1} \mathrm{yr}^{-1}$ at spacing $2 \times 2 \mathrm{~m}$. However, when using other than solid wood, early rotation may apply because the technology would determine the quality for processing.

\section{Acknowledgment}

Appreciation is addressed to directors and staffs of Centre for Forest Biotechnology and Tree Improvement that provide infrastructures, funding, and facilitate this research project. My sincere and deep thanks are also expressed to Budi Santoso Sitoputro for his passion to conduct measurements in the laboratories which some of those results were used to fulfill his study. I am also very grateful to all of my team members for their help, patience, and kindness to fulfill and finish all the jobs required to undertake this research. Special appreciation is also addressed to Prof. Dr. Budi Leksono for his meaningful advice

\section{References}

Apiolaza LA. 2009. Very early selection for solid wood quality: screening for early winners. Annals of Forest Science 66(6):601-601. https://doi.org/10.1051/ forest/2009047.

Arif A. 2018. Solusi Bagi Lahan Marginal. Harian Kompas. Senin. Halaman 14. Sains, Lingkungan dan Kesehatan. [16 April 2018]

Ashaduzzaman MD, Kayes AK, Shams MI. 2011. Natural decay resistance of Acacia auriculiformis A. Cunn. Ex Benth. and Dalbergia sissoo Roxb. Bangladesh Journal of Science and Industrial Research 46(2):225-230. https:// doi.org/10.3329/bjsir.v46i2.8189.

Baqui SA, Shah JJ. 1985. Histoenzymatic studies in wood of Acacia auriculiformis Cunn. during heartwood formation. Holzforschung 39:311-320.
Bowyer J, Shmulsky R, Haygreen JG. 2003. Forest Products and Wood Science: An Introduction. 4th Edition. Iowa: Iowa State University Press.

Bowyer J, Shmulsky R, Haygreen JG. 2007. Forest Products and Wood Science: An Introduction 5th Edition. Iowa: Blackwell Publishing.

Bulgannawar BN, Math BBM. 1991. The role of Acacia auriculiformis in afforestation in Karnataka, India. In Advances in Tropical Acacia Research. Ed. JW. Turnbull. ACIAR Proceedings no 35. Australian Centre for International Agricultural Research. Canberra.

Datta R. 1981. Acidogenic fermentation of lignocellluoseacid yield and convertion of component. Biotechnology and Bioengineering 23:2167-2170.

Des Santos Lourenço AC. 2008 The influence of Eucalyptus globulus heartwood in pulp production (thesis). Lisboa: Universidade Tecnica de Lisboa.

Demirbas A. 2001. Relationships between lignin contents and heating values of biomass. Energy Conversion and Management 42:183-188.

Demirbas A. 2002. Relationships between heating value and lignin, moisture, ash and extractive contents of biomass fuels. Energy Exploration \& Exploitation 20(1):105-111. https://doi.org/10.1260/01445980276 0170420 .

Demirbas A. 2003. Relationships between lignin contents and fixed carbon contents of biomass samples. Energy Conversion and Management 44(9):1481-1486. https://doi.org/10.1016/S0196-8904(02)00168-1.

Demirbas A. 2004. Combustion characteristics of different biomass fuels. Progress in Energy and Combustion Science 30(2):219-230. https://doi.org/10.1016/j.pecs. 2003.10.004.

Demirbas T, Demirbas C. 2009. Fuel properties of wood species. Energy Sources, Part A: Recovery, Utilization, and Environmental Effects 31(16):1464-1472. https://doi.org/10.1080/15567030802093153.

Demirbas A. 2009. Social, economic, environmental, and policy aspects of biofuels. Applied Energy. 86(Supplement 1):S108-S117. https://doi.org/10.1016/ j.apenergy.2009.04.036.

Dünisch O, Richter HG, Koch G. 2010. Wood properties of juvenile and mature hardwood in Robinia pseudoacacia L. Wood Science Technology 44:301-313.

Eberhard AA. 1990. Fuelwood calorific values in South Africa. South African Forestry Journal 152(1):17-22. https://doi.org/10.1080/00382167.1990.9629014.

Evert RF. 2006. Esau's Plant Anatomy Third edition. New Jersey: John Wiley \& Sons Inc. 
Gami B, Limbachiya R, Parmar R, Bhimani H, Patel B. 2011. An evaluation of different non-woody and woody biomass of Gujarat, India for preparation of pellets-A solid biofuel. Energy Sources, Part A: Recovery, Utilization, and Environmental Effects 33(22):2078-2088. https://doi.org/10.1080/1556703090 3503183 .

Günther B, Gebauer K, Barkowski R, Rosenthal M, Bues C. 2012, Calorific value of selected wood species and wood products. European Journal of Wood and Wood Products 70(5):755-757.

Hasan ES, Jahiding M, Mashuni, Ilmawati WOS, Wati WA, Sudiana IN. 2017. Proximate and the calorific value analysis of brown coal for high-calorie hybrid briquette application. Journal of Physics: Conference Series 846(Conference 1):012-022. https://doi.org/10.1088/ $1742-6596 / 846 / 1 / 012022$.

Hafrén J, Fujino T, Itoh T. 1999. Changes in cell wall architecture of differentiating tracheid of Pinus thunbergii during lignification. Plant Cell Physiology 40(5):532-541.

Hendrati RL, Nirsatmanto A, Baskorowati L, Fauzi A. 2011. Pemanfaatan berbagai jenis kayu energi untuk kelangsungan industri arang kayu di Jawa. Prosiding Workshop Sintesa Hasil Penelitian Hutan Tanaman. Bogor, 1 Desember 2011.

Hendrati RL, Nurrohmah SH, Susilawati S, Budi S. 2014a. Budidaya Acacia auriculiformis untuk Kayu Energi. Bogor: IPB Press.

Hendrati RL, Nurrohmah SH, Susilawati S. 2014b. Benih unggul kayu energi Calliandra calothyrsus dan Acacia auriculiformis untuk restorasi ekosistem dan antisipasi perubahan iklim. Prosiding Seminar Nasional Benih Unggul untuk Hutan Tanaman, Restorasi Ekosistem dan Antisipasi Perubahan Iklim. Yogyakarta, 1920 November 2014.

Hendrati RL. 2016. Environmentally friendly bioenergy plantations by using genetically improved legume species. Proceeding the $7^{\text {th }}$ International Conference on Green Technology. Malang, October $56^{\text {th }} 2016$.

Hills WE. 1987. Heartwood and Tree Exudates. Berlin: Springer-Verlag.

Hinchee M, Rottmann W, Mullinax L, Nehra N. 2009. Short-rotation woody crops for bioenergy and biofuels applications. In Vitro Cellular \& Developmental Biology -Plant 45(6):619-629. https://doi.org/10.1007/s11627009-9235-5.

Islam SS, Islam MS, Hossain MAT, Alam Z. 2013. Optimal rotation interval of akashmoni (Acacia auriculiformis) plantations in Bangladesh. Kasetsart Journal (Social Science) 34:181-190.
Kataki R, Konwer D. 2001. Fuelwood characteristics of some indigenous woody species of North-east India. Biomass Bioenergy 20:17-23.

Knigge W. 1993. Giant sequoia (Sequoiadendrongiganteum) in Europe. Holz Roh Werkst 51:145-155.

Krzyzaniak M, Stolarski MJ, Waliszewska B, Szczukowski S, Tworkowski J, Zaluski D, Snieg M. 2014. Willow biomass as feedstock for an integrated multi-product biorefinery. Industrial Crops and Products 58:230-237.

Korinobu S, Yomogida H, Yamaguchi K. 1990. Annual Reportfor Tree Breeding Institute 24 Mito.

McKendry P. 2002. Energy production from biomass (part 1): overview of biomass. Bioresource Technology $83: 37-46$.

Moya R, Berrocal A. 2010. Wood colour variation in sapwood and heartwood of young trees of Tectona grandis and its relationship with plantation characteristics, site, and decay resistance. Annals of Forest Science 67:109-109. https://doi.org/10.1051/ forest $/ 2009088$

Novaes E, Kirst M, Chiang V, Sederoff HW, Sederoff R. 2010. Lignin and biomass: A negative correlation for wood formation and lignin content in trees. Plant Physiology 154(1):555-561.

Panshin AJ, de Zeeuw C. 1980. Textbook of Wood Technology. Fourth Edition. New York: Mc-Graw Hill.

Peksa-Blanchard M, Dolzan P, Grassi A, Heinimö J, Junginger M, Ranta T, Walter A. 2007. Global Wood Pellet Markets and Industries: Policy Drivers, Market Status and Raw Material Potential. Utrecht: University of Technology Utrecht.

Perez D. 2004. Heartwood, sapwood and bark contents of Bombacopsis quinata in Costa Rica. Journal of Tropical Forest Science 16(3):318-327.

Santana WMS, Calegario N, Arantes MDC, Trugilho PF. 2012. Effect of age and diameter class on the properties of wood from clonal Eucalyptus. Cerne Lavras Journal 18(1):18. https://doi.org/10.1590/S010477602012000100001

Sitoputro BS. 2014. Analisis kandungan Lignin pada heartwood dan sapwood Acacia auriculiformis A. Cunn. Ex Benth. [undergraduated thesis]. Yogyakarta: Faculty of Biology, Gadjah Mada University.

Stolarski MJ, Krzyzaniak M, Snieg M, Slomiñska E, Piórkowski M. Filipkowski R. 2014. Thermophysical and chemical properties of perennial energy crops depending on harvest period. International Agrophysics. 28:201-211. https://doi.org/10.2478/intag-2014-0009.

Sunarti S, Na'iem M, Hardiyanto EB, Indrioko S. 2013. Breeding strategy of acacia hybrid (Acacia mangium $\times$ 
A. auriculiformis) to increase forest plantation productivity in Indonesia. Jurnal Manajemen Hutan Tropika. 19(2):128-138. https://doi.org/10.1093/ aob/mcp118.

Syachri TN. 1983. Sifat Arang, Briket Arang dan Alkohol yang Dibuat dari Limbah Industri Kayu. Bogor: Laporan PPPHH Bogor No. 165.

Supartini. 2009. Komponen kimia kayu meranti kuning (Shorea microbalanos). Jurnal Penelitian Dipterokarpa 3(1):43-50.

Susanto M, Prayitno TA, Fujisawa Y. 2008. Wood genetic variation of Acacia auriculiformis at Wonogiri Trial in Indonesia. Journal of Forestry Research 5 (2):125-134.

Tullus A, Ryytter R, Tullus T, Weih M, Tullus H. 2012. Short-rotation forestry with hybrid aspen (Populus tremula L. $\times$ P. tremuloides Michx.) in Northern Europe. Scandinavian Journal of Forest Research 27: 10-29.

White R. 1987. Effect of lignin content and extractives on the higher heating value of wood. Wood and Fiber Science 19(4):446-452.
Wilson TO. 2010. Factors affecting wood pellet durability (thesis). Pensylvania: Pensylvania State University.

Wong ML, Cannon CH, Wickneswari R. 2011. Identification of lignin genes and regulatory sequences involved in secondary cell wall formation in Acacia auriculiformis and Acacia mangium via de novo transcriptome sequencing. BioMedical Central Genomics 12:342. https://doi.org/10.1186/1471-2164-12-342.

Zhigang P, Minquan Y. 1987. Australian acacias in the People's Republic of China in Australian Acacias in Developing Countries, ACIAR (Australian Centre for International Agricultural Research) Proceedings No. 16, Editor Turnbull JW, Brown Prior Anderson Pty Ltd, Victoria, Australia.

Zhonglian H. 2009. Identification and characterization of genes involved in heartwood formation in black walnut (Juglans nigra L) (dissertation). Indiana: Purdue University.

Zobel BJ, Jett JB. 1995. Genetics of Wood Production. London: Springer-Verlag. 